\title{
Possible Effects of Groundwater Pumping on Surface Water in the Verde Valley, Arizona
}

he U.S. Geological Survey
(USGS), in cooperation with
The Nature Conservancy, has
applied a groundwater model to
simulate effects of groundwater
pumping and artificial recharge
on surface water in the Verde
Valley sub-basin of Arizona.
Results are in two sets of maps
that show effects of locations
of pumping or recharge on
streamflow. These maps will
help managers make decisions
that will meet water needs and
minimize environmental im-
pacts.

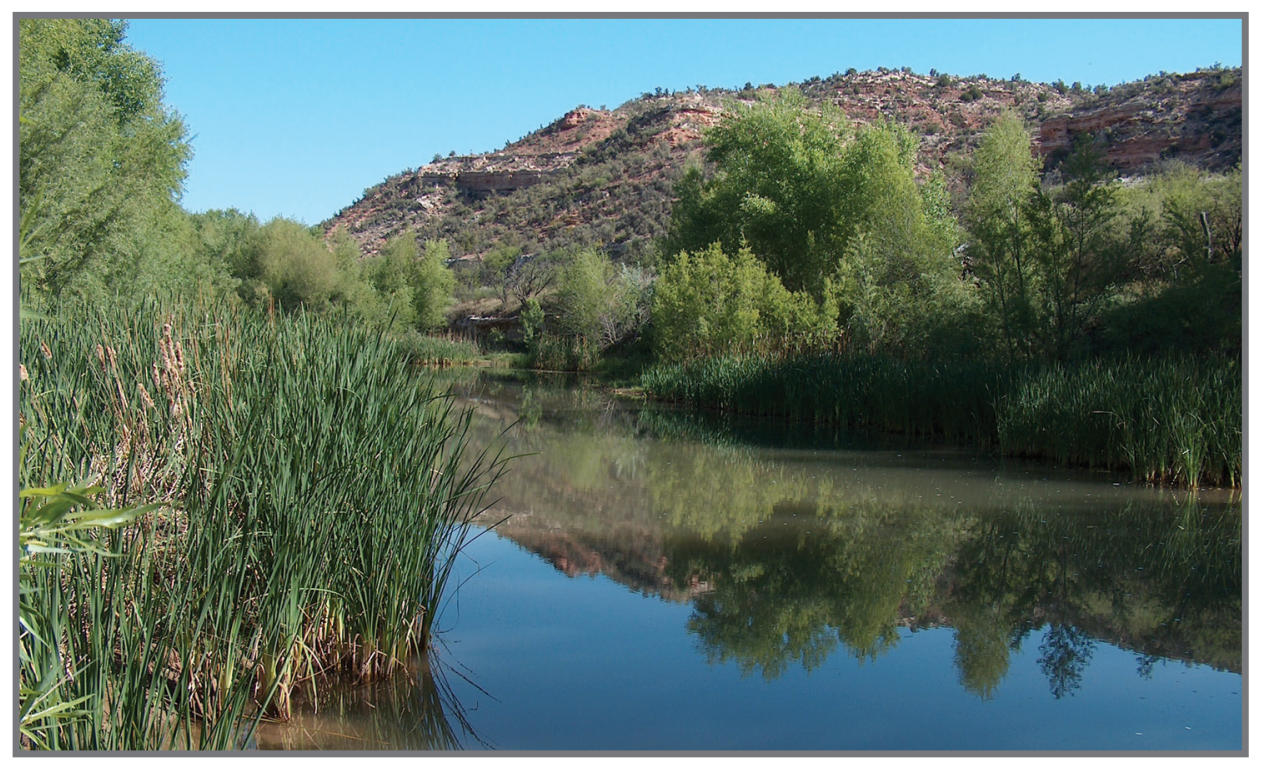

Figure 1. Verde River Greenway below Deadhorse Ranch State Park, Cottonwood, Arizona. (Photograph by Jeanmarie Haney, The Nature Conservancy.)

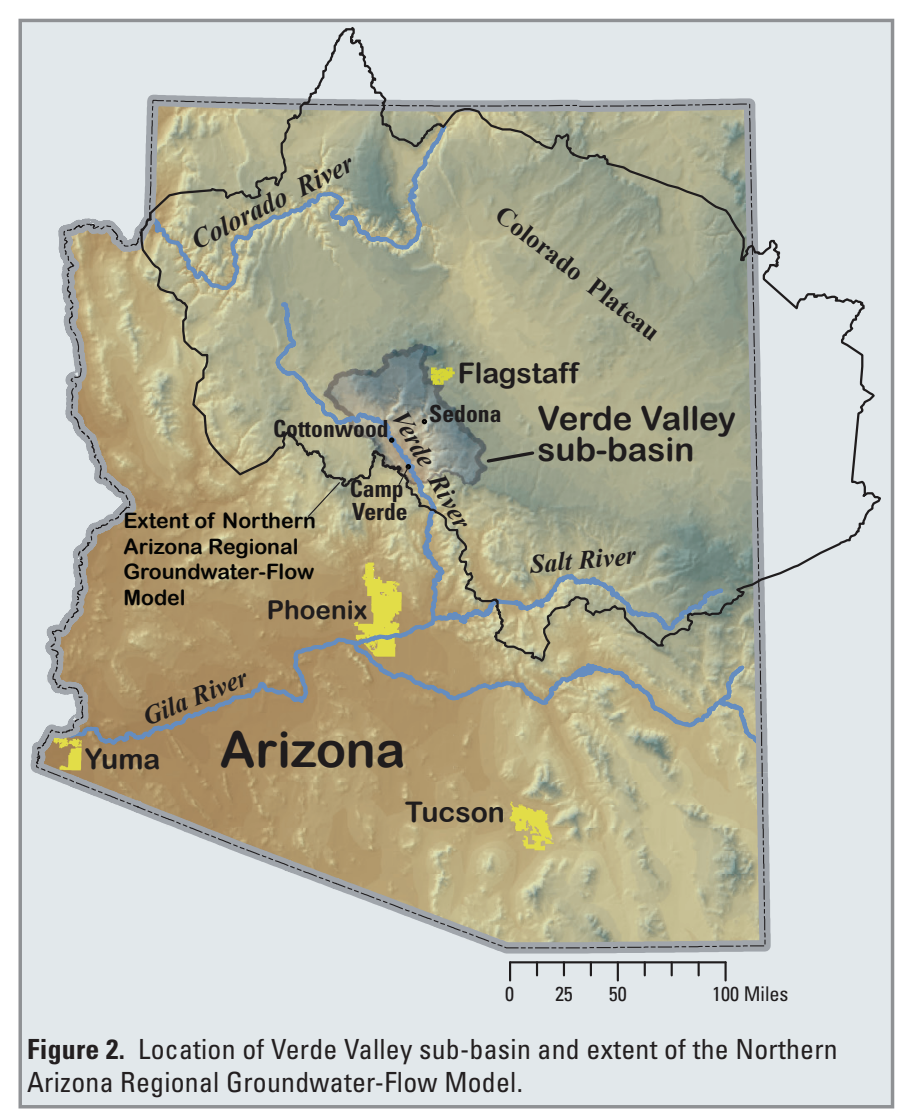

The Verde Valley sub-basin of north-central Arizona (figs.1, 2) is favored with year-round flowing streams. Although surface water is diverted from the Verde River for agriculture and landscaping, nearly all water for public, domestic, and industrial supplies comes from groundwater pumping (Blasch and others, 2006). Groundwater use in the sub-basin increased more than tenfold in the latter half of the 20th century. A growing awareness of sustainable water management recognizes that development of groundwater affects connected surface water. With increasing population and water use, sustainability of water resources and long-term health of the Verde River are of concern.

Detailed information about surface-water and groundwater resources and their interconnections can help water managers and elected officials make good water-development decisions that minimize environmental impacts. A technique developed by the U.S. Geological Survey (USGS) allows use of a groundwater-flow model to map the effects of groundwater pumping or artificial recharge on surface water through time. This technique has been applied in the Verde Valley and a detailed scientific report is available on the Internet (Leake and Pool, 2010, http://pubs.usgs.gov/sir/2010/5147/). This fact sheet presents basic information from the scientific report to help water managers and others understand possible long-term effects of groundwater pumping or artificial recharge on the Verde River and adjacent groundwaterdependent vegetation.

\section{Overview of Groundwater and Aquifers in the Verde Valley}

When useful amounts of water can be extracted from a well, the subsurface material that contains the water is called an "aquifer." Aquifers may consist of loose materials, such as sand, gravel, silt, and clay, or of solid rock, such as sandstone, limestone, or siltstone. Water occupies the open space between grains and in fractures. Aquifers may be stacked one upon another. Water enters aquifers from rain and snowmelt that percolates to the water table. Water moves through the aquifer system 
and eventually flows out at lower elevations. Where the land surface intersects water-filled sediments or fractures, groundwater becomes surface water and supports flow and habitat at a spring, river, or wetland.

In the Verde Valley, groundwater is present in several aquifer layers. The upper part of the Verde Formation consists mostly of limestone and siltstone, and the lower part mostly of sand and gravel. Beneath the Verde Formation and extending laterally under Sedona is the "C aquifer," dominated by rocks of the Supai Group. Beneath the $\mathrm{C}$ aquifer is the " $\mathrm{R}$ aquifer," dominated by rocks of the Redwall Limestone.

\section{How Groundwater Pumping Affects Surface Water and Riparian Vegetation}

Under natural or "predevelopment" conditions, long-term average rates of inflow to and outflow from an aquifer system are equal. Removal of groundwater by wells changes an aquifer system through time. Figure 3 shows the development of a "cone of depression" in the water table around a well and the later effects as that cone expands to a nearby stream and area of trees that use groundwater. Figure 4 shows that when pumping starts, all of the pumped water comes from storage in the aquifer. As pumping time continues, however, a greater percentage of the pumping can come from "depletion," which is reduced flow in the stream and reduced use of groundwater (evapotranspiration) by plants. At any time, the only sources of pumped water are aquifer storage and reduced streamflow and evapotranspiration. Percentages of these sources vary through time and are affected by distance to the surface water, as shown in figure 4 , and by the properties of the aquifer.

\section{The Northern Arizona Regional Groundwater-Flow Model (NARGFM)}

Because the aquifer system underlying the Verde Valley subbasin is complex, a groundwater flow model is needed to understand the timing of effects of groundwater pumping on surface water and riparian vegetation. The USGS developed the Northern Arizona Regional Groundwater-Flow Model (NARGFM; Pool and others, in press) - the most comprehensive and up-to-date groundwater-flow model that includes the sub-basin. NARGFM simulates groundwater flow in an area much larger than the sub-basin, including parts of the Colorado Plateau, the Verde River Basin, and adjacent areas (fig. 2). In spite of the large extent of the model, it is well suited to simulate general conditions in the Verde Valley sub-basin.

NARGFM uses three distinct layers to simulate the different aquifers underlying the Verde Valley. The upper model layer (layer 1) represents the upper Verde Formation. The middle model layer (layer 2) represents chiefly the lower Verde Formation and the $\mathrm{C}$ aquifer but also includes volcanic rocks. The lower model layer (layer 3) represents chiefly the $\mathrm{R}$ aquifer. For details on the model and attributes for streams and springs in the Verde Valley sub-basin, see Pool and others (in press).

\section{Possible Effects of Groundwater Pumping on Streamflow in the Verde Valley}

Using NARGFM to estimate effects of groundwater pumping on surface water and riparian vegetation in the Verde Valley is a process that requires numerous steps and calculations. The results are presented in maps that show the total reduced streamflow as a percentage of pumping rate. Thus, estimated depletion for any pumping rate can be determined for any pumping location. Estimated streamflow enhancement from artificial recharge can also be determined, with certain caveats. For more details on the method, see Leake and Pool (2010).

Because depletion of streamflow by groundwater pumping (or enhancement of streamflow by artificial recharge) is location and time dependent, a reference time period must be chosen to examine effects at any given location. Streamflow depletion also varies depending on the aquifer (model layer) in which pumping is occurring. Results at 10 and 50 years for pumping from model layers 1 and 2 are shown in figures 5 and 6 . Simulated depletion for layer 3 is not presented in this study. Results for layers 1 and 2 are contoured as the percentage of the pumping rate that is derived from streamflow and evapotranspiration. Percentages are color-coded, as shown in the color bar at the bottom of figures 5 and 6 . The procedure for using the maps to calculate depletion for a single well is shown in figure 7.

Results for layer 1 (for a well pumping from the upper Verde Formation at a constant rate) are shown in figure 5. At a pumping time of 10 years (fig. $5 A$ ), results indicate greatest percentages of streamflow depletion (yellow to red colors) along the Verde River between Clarkdale and Cottonwood and from several miles upstream of Camp Verde down to the sub-basin boundary. Depletion is also higher along Oak Creek upstream and downstream from Cornville. Values are lower along an 11-mile stretch of the Verde River below Cottonwood. Results for layer 1 for a well pumping at a constant rate for 50 years (fig. $5 B$ ) indicate similar patterns, but with higher overall percentages of streamflow depletion because of the additional pumping time. Numerous municipal and private water-company wells, and thousands of individually owned domestic wells, pump from this aquifer.

Results for layer 2 (C aquifer) are shown in figures $6 A$ and $6 B$. Because layer 2 covers a greater extent of the Verde Valley than does layer 1, the maps in figure 6 show a larger area, nearly the entire subbasin, extending beyond Sedona and to the northwest of Flagstaff. Results indicate that for a pumping time of 10 years (fig. $6 \mathrm{~A}$ ), the greatest percentages of streamflow depletion (yellow to red colors) occur along the Verde River upstream from Cottonwood and downstream from Camp Verde, along reaches of Oak Creek, and along Wet Beaver Creek upstream from Rimrock. Results for layer 2 at a pumping time of 50 years (fig. $6 B$ ) indicate general increases in effects along the streams and at greater

A. When a well begins to pump, all of the water pumped comes from storage in the aquifer, creating a "cone of depression."

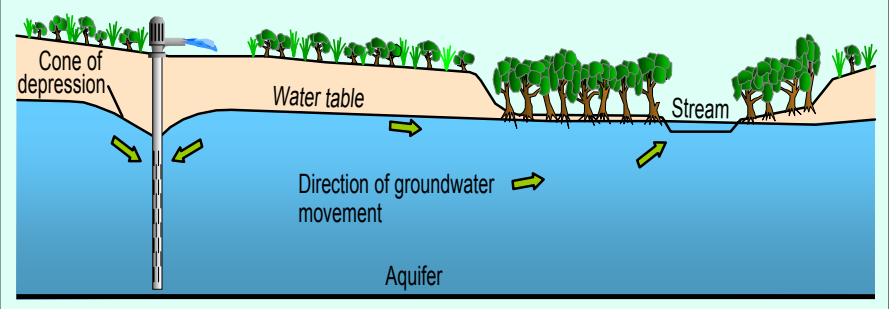

$\boldsymbol{B}$. With time, the cone of depression can spread to areas of surface water and trees that use groundwater. In this example, the pumping has taken all of the groundwater inflow to the stream in the area of the well and has further caused the stream to lose water to the aquifer.

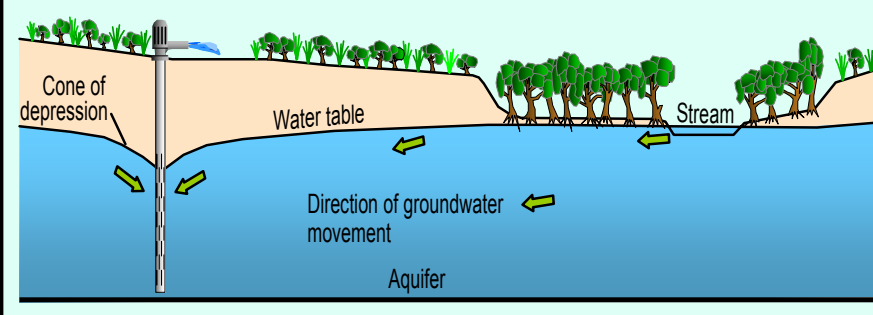

C. If the stream cannot supply the rate of water pumped, it may become disconnected from the water table, resulting in an ephemeral stream. The lowered water table also may result in loss of trees that depend on groundwater.

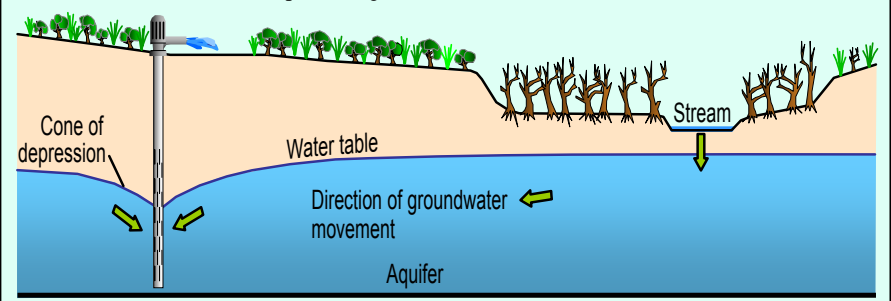

Figure 3. Diagram showing progressive effects of groundwater pumping on the water table, a nearby stream, and an area of trees that use groundwater (modified from Webb and others, 2007). 
distances from them. Many of the private water company wells in the Sedona area pump from this aquifer.

\section{Applicability and Limitations}

The procedures used for the analysis described here depict responses to pumping or artificial recharge over large areas of an aquifer. The results are meant to give resource managers and the public a general understanding of areas in which pumping would result in faster or slower responses in surface-water flow and evapotranspiration. The distributions shown on figures 5 and 6 do not mean that groundwater pumping is appropriate or even technically feasible at all locations. Responses shown are based on features represented in the part of the NARGFM underlying the Verde Valley sub-basin. Although NARGRM is the most comprehensive and up-to-date tool available to examine effects from groundwater pumping in the sub-basin, it is a regional model that cannot represent a high degree of local detail. For more information on these and other technical aspects of the results presented here, see Leake and Pool (2010).

\section{References}

Blasch, K.W., Hoffmann, J.P., Graser, L.F., Bryson, J.R., and Flint, A.L., 2006, Hydrogeology of the upper and middle Verde River watersheds, central Arizona: U.S. Geological Survey Scientific Investigations Report 2005-5198, 102 p., 3 plates, accessed July 14, 2010, at http://pubs.usgs.gov/sir/2005/5198/.

Leake, S.A., and Pool, D.R., 2010, Simulated effects of groundwater pumping and artificial recharge on surface-water resources and

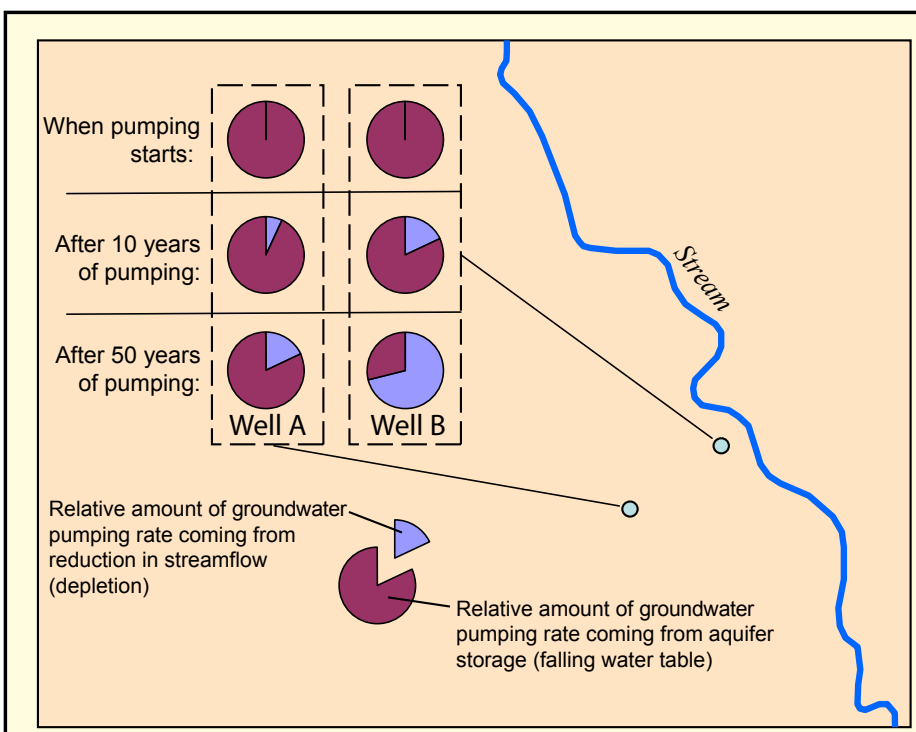

Figure 4. Sources of pumped groundwater at two hypothetical well locations for pumping times of 10 and 50 years.

riparian vegetation in the Verde Valley sub-basin, central Arizona: U.S. Geological Survey Scientific Investigations Report 2010-5147,

18 p., accessed October 1, 2010, at http://pubs.usgs.gov/sir/2010/5147/. Pool, D.R., Blasch, K.W., Callegary, J.B., Leake, S.A., and Graser, L.F., in

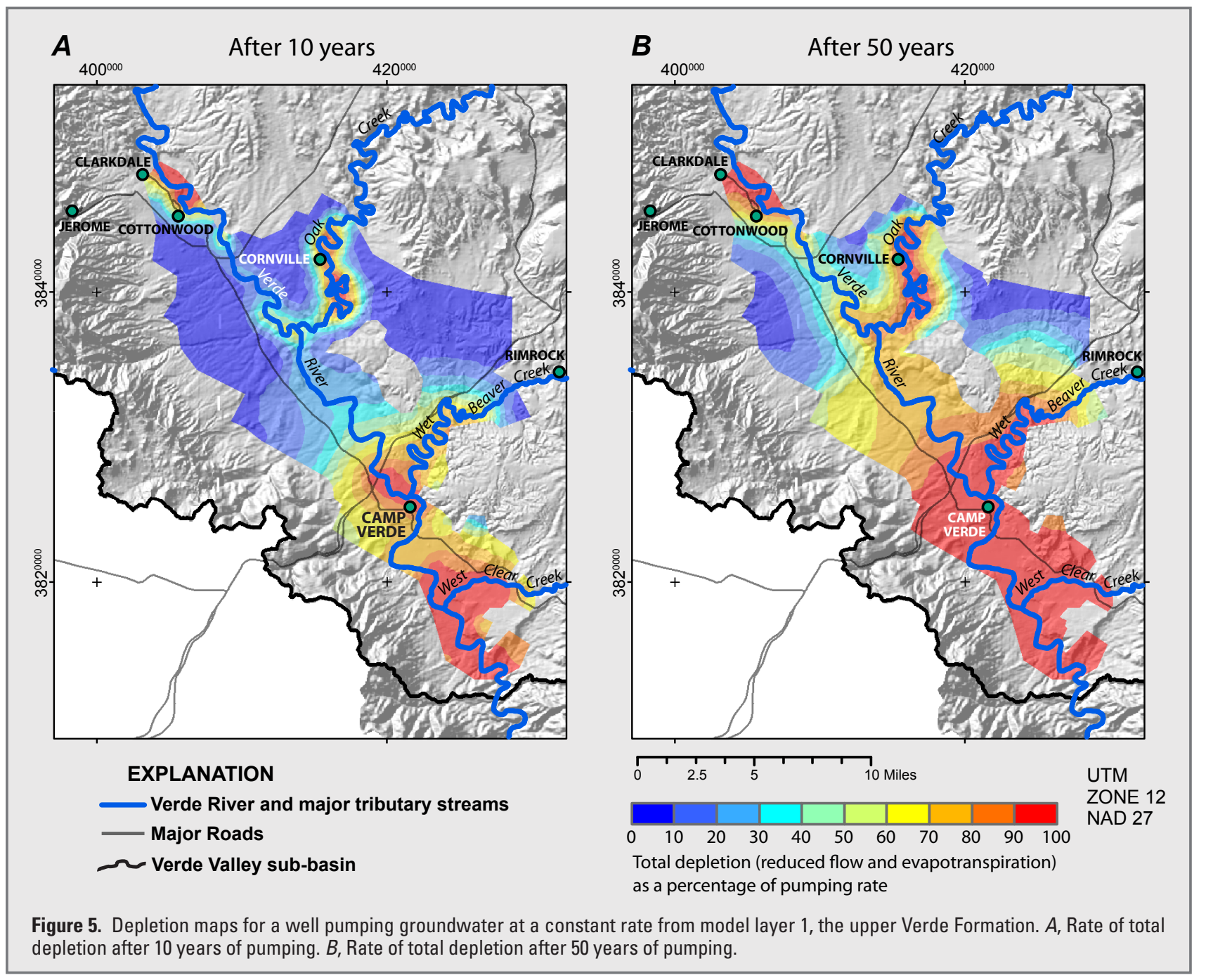



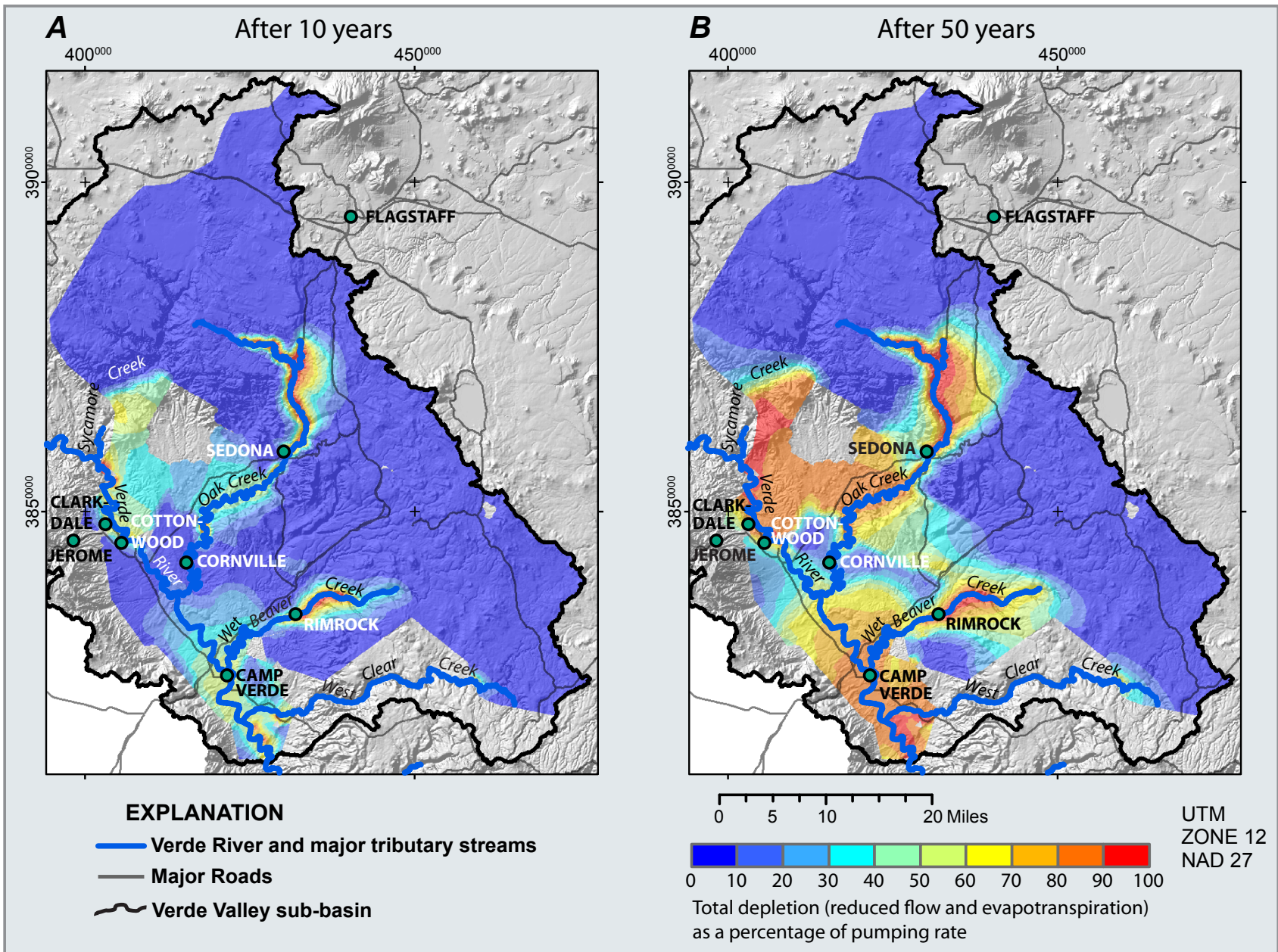

Figure 6. Depletion maps for a well pumping groundwater at a constant rate from model layer 2, the lower Verde Formation, the Supai Group, and volcanic rocks. $A$, Rate of total depletion after 10 years of pumping. $B$, Rate of total depletion after 50 years of pumping.

\section{EXAMPLE USE OF MAPS TO CALCULATE DEPLETION FOR A SINGLE WELL \\ Well pumps an average of 10 acre-feet per year from the upper part of the Verde Formation for 50 years}

\section{Step 1-Select the right map \\ - Use figures $5 A$ and $5 B$ for wells open in the upper part of the Verde Formation. - Use figures $6 A$ and $6 B$ for wells open in the lower part of the Verde Formation, the Supai Group, and volcanic rocks.}

Step 2-Find the location of the well on the map

Step 3-Note the percent range on the color bar corresponding to color at well location on map

In this example the range is 60 to 70 percent.

Step 4-Multiply corresponding fraction for color range by average well pumping rate to get average depletion rate

For the depletion range of 60 to 70

percent in this example, use a fraction of 0.65. Calculation is $0.65 \times 10$ acre-feet per year $=6.5$ acre-feet per year of depletion at a pumping time of 50 years.

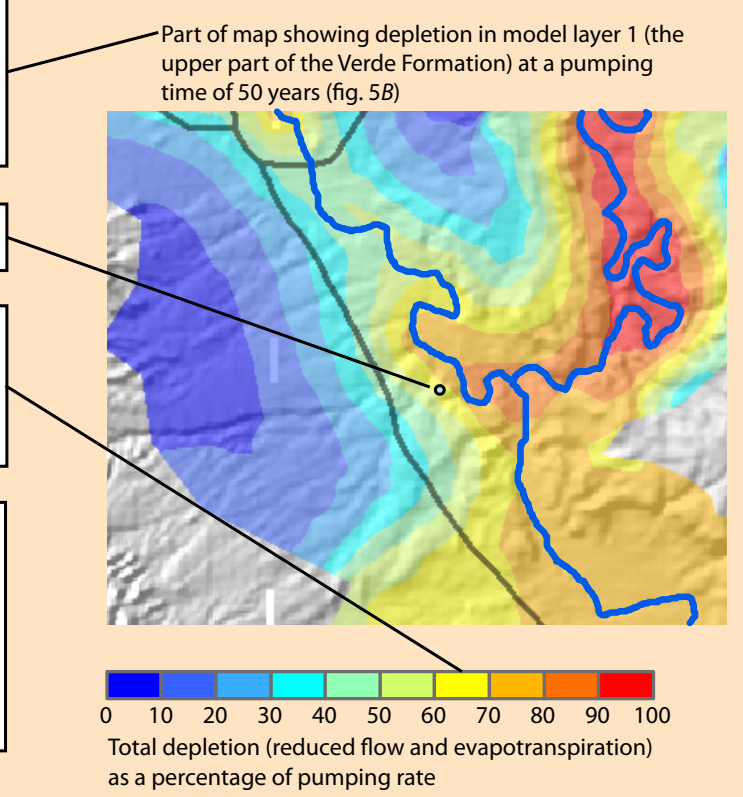

Figure 7. An example of the application of depletion maps such as shown in figures 4 and 5. press, Regional groundwater-flow model of the Redwall-Muav, Coconino, and Alluvial Basin aquifer systems of northern and central Arizona: U.S. Geological Survey Scientific Investigations Report 2010-5180.

Webb, R.H., Leake, S.A., and Turner, R.M, 2007, The ribbon of green - change in riparian vegetation in the Southwestern United States: Tucson, University of Arizona Press, 480 p.

Stanley A. Leake (USGS) and Jeanmarie Haney (The Nature Conservancy) Edited by Peter H. Stauffer

Graphic design by Stephen L. Scott

COOPERATING ORGANIZATION The Nature Conservancy

For more information contact: Stanley A. Leake U.S. Geological Survey Arizona Water Science Center 520 N. Park Ave, Suite 221 Tucson, AZ 85719 Email: saleake@usgs.gov

This Fact Sheet and any updates to it are available online at: http://pubs.usgs.gov/fs/2010/3108/ 